\title{
STANJE NASLEDSTVA NA HRIBOVSKIH KMETIJAH V SLOVENIJI
}

\author{
dr. Boštjan Kerbler - Kefo \\ Urbanistični inštitut Republike Slovenije \\ Trnovski pristan 2, SI- I000 Ljubljana, Slovenija \\ e-mail: bostjan.kerbler@guest.arnes.si
}

Izvirni znanstveni članek

COBISS 1.01

\section{Izvleček}

Prispevek izhaja iz domneve, da uradni statistični podatki ne izražajo dejanskega stanja nasledstva na hribovskih kmetijah v Sloveniji oziroma na slovenskih kmetijah v splošnem, saj popisni kriteriji za opredelitev nasledstva niso popolni. Da bi potrdili našo domnevo, smo oblikovali natančnejše kriterije in določili, kakšno je v resnici stanje nasledstva na hribovskih kmetijah v Sloveniji. Izkazalo se je, da je ugodnejše, kot kaže uradna statistika.

Ključne besede: kmetijstvo, agrarna geografija, hribovske kmetije, nasledstvo na kmetijah

\section{SUCCESSION STATUS ON MOUNTAIN FARMS IN SLOVENIA}

\begin{abstract}
This paper is based on the hypothesis that the official statistical data does not reflect actual succession status on mountain farms in Slovenia and also on Slovene farms in general, since the census criteria defining succession are still incomplete. With the purpose of confirming our assumption, we formulated more accurate criteria and also determined as to what is the real status of succession on mountain farms in Slovenia. It has proved to be more favourable, than it is presented by the official statistics.
\end{abstract}

Key words: agriculture, agricultural geography, mountain farms, farm succession 


\section{UVOD}

Po Popisu kmetijskih gospodarstev iz leta 2000 kar 77 \% slovenskih kmetij nima izbranih naslednikov. Za hribovske kmetije je delež nekoliko nižji in znaša 67,2 \%, vendar je še vedno zaskrbljujoč, zlasti ker je »zagotavljanje (inter)generacijske kontinuitete odločilnega pomena pri ohranjanju tradicije kmetovanja (Hribernik 1994, 35) in ker so hribovske kmetije najpomembnejše prvine hribovske kulturne pokrajine. Hkrati je delež tudi neobičajno visok, zato smo domnevali, da ni pravilen. Podatke popisa, zlasti način njihovega pridobivanja, smo zato analizirali podrobneje in izkazalo se je, da je dvom upravičen. V popisu so namreč kot nasledniki opredeljene osebe, ki naj bi za sedanjim gospodarjem prevzele in vodile kmetijo (Statistični urad Republike Slovenije 2003), popisovalci pa so jih na popisnem listu imeli možnost označiti le kot osebe, ki živijo v gospodarjevem gospodinjstvu. To pomeni, da so bile kmetije, na katerih nasledniki ne živijo v istem gospodinjstvu kot gospodarji, opredeljene kot kmetije brez naslednikov, čeprav so ti nasledniki že določeni, predvideni ali celo že vodijo kmetije, uradno pa jih še niso prevzeli, živijo pa lahko tudi na istih kmetijah kot gospodarji, vendar v ločenih gospodinjstvih, kar je na kmetijah zelo pogosto.

Da bi potrdili svojo domnevo in določili (ugotovili), kakšno je v resnici stanje nasledstva na hribovskih kmetijah v Sloveniji, smo opravili obsežno raziskavo in v ta namen oblikovali natančnejše kriterije za opredelitev nasledstva.

\section{TERMINOLOGIJA}

Zaradi prilagoditve uporabljenim podatkovnim virom in zaradi oblikovanja čim enovitejše ciljne skupine, so v prispevku kot hribovske kmetije opredeljene kmetije:

- ki so po Robičevi $(1988,1990)$ členitvi območij z omejenimi dejavniki za kmetovanje v gorsko-višinskem območju, na več kot 600 m nadmorske višine, in tudi kot kmetije, ki se nahajajo pod 600 m nadmorske višine, vendar imajo več kot 60 \% kmetijskih zemljišč v nagibu nad $35 \%$ (t.i. strme kmetije);

- ki se nahajajo v alpski ali predalpski Sloveniji, pri čemer smo območje alpskih in predalpskih pokrajin Slovenije določili na podlagi Ilešičeve naravnogeografske regionalizacije iz leta 1972;

- na katerih je glavna proizvodna usmeritev živinoreja - reja pašne živine ali mešana živinoreja;

- na katerih so gospodarji stari 45 let ali več let.

\section{METODOLOGIJA}

\section{I Izbor pristopa proučevanja in podatkovnega vira}

Pri raziskavah o nasledstvu na kmetijah ločimo dva pristopa: pristop ex-ante in pristop ex-post. Pri pristopu ex-ante gre za ugotavljanje stanj nasledstva na kmetijah na podlagi dogodkov, ki se v zvezi z nasledstvom še niso zgodili, vendar je izid dogodkov predviden oziroma načrtovan - t.i. načrtovano (predvideno) nasledstvo na kmetijah (angleško planned 
farm succession). Pri pristopu ex-post pa gre za ugotavljanje stanj nasledstva na kmetijah na podlagi dogodkov, ki so se v zvezi z nasledstvom že zgodili - t.i. dejansko nasledstvo na kmetijah (angleško actual farm succession) (medmrežje 1; medmrežje 2). Na podlagi tega pristopa lahko o stanjih nasledstva na kmetijah sklepamo tudi posredno, in sicer z ugotavljanjem dejanskega prenehanja gospodarjenja na kmetijah in opuščanja ali obdržanja kmetij (angleško farm exit, farm survival).

Med raziskavami, v katerih so se ukvarjali s proučevanjem nasledstva na kmetijah oziroma prenehanja gospodarjenja na kmetijah in opuščanja ali obdržanja kmetij, prevladujejo raziskave, ki temeljijo na pristopu ex-post ${ }^{1}$. Prednost pristopa ex-post pred pristopom exante je namreč v tem, da se analizirajo dogodki, ki so se v zvezi z nasledstvom na kmetiji dejansko zgodili in niso samo predvidevanja o tem, kar naj bi se dogajalo v prihodnosti, kot je to značilno za pristop ex-ante. Predvidene namere posameznikov se namreč dejansko uresničijo le pod strogo omejenimi pogoji, ki jih je v realnosti težko doseči. Pri izvrševanju namere ne sme biti nobenih ovir, stanje posameznika s predvideno namero in okoliščine pa se ne smejo spreminjati od pridobitve podatkov in ves čas posameznikovega izvrševanja ravnanja v zvezi z namero (Foxall 1983; povzeto po Väre in sod. 2006). Po Horowitzu (1992; povzeto po Väre in sod. 2006) mora torej obstajati t.i. medčasovna konsistentnost (angleško intertemporal consistency).

Glede na opisane prednosti pristopa ex-post smo želeli tudi v svoji raziskavi proučiti dejansko nasledstvo na hribovskih kmetijah v Sloveniji. Ker so bili v raziskavah, ki temeljijo na pristopu ex-post, uporabljeni podatki, ki jih zbirajo različne statistične in druge državne službe - gre namreč za opazovanje stanja med dvema časovnima obdobjema (v glavnem gre za pet- ali desetletno obdobje) - smo dejansko nasledstvo na hribovskih kmetijah v Sloveniji želeli določiti na podlagi podatkov zadnjih dveh zaporednih popisov, in sicer Popisa prebivalstva, gospodinjstev in kmečkih gospodarstev v letu 1991 ter Popisa kmetijskih gospodarstev leta 2000. Pogoj pri tem je bila identifikacija posamezne kmetije, saj je le tako mogoče na posamezni kmetiji ugotavljati stanje nasledstva (na podlagi spremembe starosti gospodarja, dodatno pa tudi na podlagi spremembe imena in priimka gospodarja med obema popisoma) ter obstoj kmetije med obema popisoma ${ }^{2}$. Vendar pa smo se pri tem morali soočiti z nepremostljivo težavo - neusklajenostjo podatkovnih virov. V popisu iz leta 1991 so bili namreč nosilci kmetij identificirani na podlagi EMŠO-ja, ki v popisu leta 2000 ni bil ključni podatek, identifikacija kmetije prek naslova, na katerem je kmetija, ter imena in priimka nosilca kmetije pa prav tako ni bila mogoča, saj je bil to manjkajoči podatek v popisu iz leta 1991.

\footnotetext{
1 Dejansko nasledstvo na kmetijah so proučevali: Gale (1993), Stiglbauer in Weiss (2000), Väre in Weiss (2003), Väre in sod. (2006), Pietola in sod. (2003), dejansko prenehanje gospodarjenja na kmetijah in opuščanje ali obdržanje kmetij pa Kimhi in Bollman (1999), Weiss (1999a; 1999b), Juvančič (2002; 2006) ter Glauben in sod. (2003).

${ }^{2}$ Opustitev kmetije smo želeli preveriti na podlagi njene evidence, in sicer bi kmetijo, ki bi bila v prvem popisu evidentirana, v drugem pa ne, opredelili kot opuščeno. Posebej bi obravnavali tudi kmetije, ki bi sicer v drugem popisu bile evidentirane (ne glede na to, ali je na njih do nasleditve prišlo ali ne), vendar pa se na njih s kmetovanjem ne bi več ukvarjali.
} 
Pomembni oviri pri proučitvi dejanskega nasledstva na hribovskih kmetijah v Sloveniji sta bili tudi različni definiciji kmetije $\mathrm{v}$ omenjenih popisih. $\mathrm{V}$ primerjavi s popisom iz leta 1991 so bile v popis kmetijstva iz leta 2000 vključene le kmetije, ki so ustrezale velikostnim merilom EU, t.i. evropsko primerljive kmetije - EPK (Dernulc in sod. 2002). Preostale kmetije iz popisa leta 1991, ki v popis kmetijstva iz leta 2000 niso bile vključene, so bile kmetije, ki po Kovačiču (1996) ne dosegajo mejnih vrednosti opredelilnih kriterijev - Kerbler (2002; 2003a; 2003b) jih je poimenoval podstandardne kmetije oziroma NE-EPK - in kmetije, ki so po kriterijih EU sicer sodile med EPK, vendar je bilo v popisu kmetijstva iz leta 2000 zabeleženo, da iz različnih razlogov ne obstajajo več.

Če bi analizo dejanskega nasledstva na hribovskih kmetijah lahko izvedli, bi morali vanjo vključiti le kmetije, ki bi jih na podlagi popisa iz leta 1991 opredelili kot EPK, in sicer ne glede na to, ali so leta 2000 obstajale ali ne (dejansko nasledstvo na njih bi ugotavljali med tistimi, ki so leta 2000 še vedno obstajale).

Čeprav bi se proučevano obdobje skrajšalo in bi bila zaradi tega relevantnost rezultatov vprašljiva, smo podatke iz popisa leta 1991 poskušali nadomestiti s podatki iz Vzorčnega popisa osnovnih zmogljivosti kmetij, ki je bil izveden v Sloveniji v letu 1997, in podatki Raziskovanja strukture kmetijskih gospodarstev leta 2003, vendar tudi ta rešitev ni bila izvedljiva. Pri popisu iz leta 1997 identifikacija posameznih kmetij v Popisu kmetijskih gospodarstev leta 2000 in sledenje spremembam pri njih zaradi metodološko-tehničnih razlik ni bi bila mogoča. Za popis iz leta 2003 je Odbor za varstvo podatkov pri Statističnem uradu Republike Slovenije odločil, da nam urad podatkov za posamezne kmetije ne more posredovati, saj jih ne bi mogli zaščititi na način, ki bi onemogočal povezavo z nezaščitenimi podatki za posamezne kmetije v Popisu kmetijskih gospodarstev leta 2000, ki so nam jih pred tem že posredovali za analizo nasledstva na hribovskih kmetijah v Sloveniji.

Zaradi predstavljenih pomanjkljivosti podatkovnih virov smo za ugotavljanje stanja nasledstva na hribovskih kmetijah v Sloveniji namesto pristopa ex-post izbrali pristop exante. Tudi pri tem pristopu so lahko vir za analizo podatki različnih statističnih in drugih državnih služb - v raziskavah načrtovanega (predvidenega) nasledstva na kmetijah sta jih na primer uporabila Tietje (2003) in Corsi (2004) - vendar Popis kmetijskih gospodarstev leta 2000, ki sicer vključuje podatek o načrtovanem (predvidenem) nasledstvu na kmetijah, zaradi v uvodu opisane pomanjkljive definicije naslednika za našo raziskavo ni bil primeren. Kot večina empiričnih raziskav, ki temelji na pristopu ex-ante $e^{3}$, smo zato načrtovano (predvideno) nasledstvo na hribovskih kmetijah v Sloveniji analizirali na podlagi podatkov, pridobljenih z anketiranjem. Po mnenju Glaubna in sod. (2002), Tietja (2003) ter Väre in sod. (2006), ki se pri tem navezujejo na strokovnjake z različnih raziskovalnih področij (ekonomija, psihologija itd.), ima anketa pri proučevanju nasledstva na kmetijah v primerjavi s podatkovnimi viri statističnih in drugih državnih služb tudi številne prednosti. Navajajo namreč, da lahko z njo pridobimo tudi številne podrobne informacije o predvidenih namerah in motivih za obnašanja ter ravnanja posameznikov v zvezi z nasledstvom in s kmetovanjem v prihodnje, stanja nasledstva na kmetiji pa lahko opredeli raziskovalec sam.

3 Pfeffer (1989), Fasterding (1995; 1999), Kimhi in Lopez (1999), Kimhi in Nachlieli (2001), Hennessey (2002; 2004), Glauben, Tietje in Weiss (2002; 2004), Tietje (2003; 2004), Corsi (2004). 


\subsection{Opredelitev stanj nasledstva na kmetijah}

Da bi pri določitvi stanj nasledstva na hribovskih kmetijah v Sloveniji presegli pomanjkljivosti Popisa kmetijskih gospodarstev 2000, smo naslednika opredelili kot osebo, ki bo za gospodarjem prevzela kmetijo in jo vodila, zanjo pa ni nujno, da živi v istem gospodinjstvu kot gospodar in da je gospodarjev potomec. Če namreč oseba, ki bo za sedanjim gospodarjem prevzela kmetijo, namerava nadaljevati s kmetovanjem in s tem vplivati, da kmetija ne bo propadla, ni razlogov za to, da mora biti ta oseba gospodarjev potomec oziroma da mora živeti v istem gospodinjstvu.

Poleg opredelitve naslednika smo pri določitvi stanj nasledstva na hribovskih kmetijah v Sloveniji upoštevali še dodatne kriterije:

a) ali je naslednik na kmetiji že natančno določen oziroma ali je nekdo za to že predviden;

b) ali se je naslednik že sam odločil, da bo prevzel kmetijo, oziroma ali se bo naslednik zagotovo odločil, da bo prevzel kmetijo;

c) ali bo naslednik po prevzemu kmetije nadaljeval s kmetovanjem;

d) ali bodo na kmetiji zagotovo našli in določili naslednika, ki bo prevzel kmetijo in tudi nadaljeval s kmetovanjem.

K a) Če naslednik na kmetiji še ni natančno določen, smo kriterij dopolnili z možnostjo, da je nekdo za to že predviden, vendar pa se kriterij v obeh primerih nanaša na gospodarjevo mnenje, ki ni odvisno od tega, ali se je oseba, določena oziroma predvidena za naslednika, že tudi sama odločila, da bo kmetijo prevzela.

$\mathrm{K}$ b) Kriterij, ki izraža naslednikovo odločitev glede prevzema kmetije, smo oblikovali za kmetije, na katerih so po mnenjih gospodarjev nasledniki natančno določeni ali predvideni. Za kmetije, na katerih nasledniki še niso sprejeli odločitve glede prevzema kmetije, smo kriterij dopolnili z mnenjem gospodarjev, ki pomeni njihovo zagotovilo o tem, ali se bo naslednik odločil, da bo prevzel kmetijo.

$\mathrm{K}$ c) Kriterij se nanaša na naslednikove namere glede nadaljnjega kmetovanja po prevzemu kmetije.

K d) Na kmetijah, na katerih nasledniki še niso natančno določeni in za to ni še noben predviden, ter na kmetijah, na katerih so sicer osebe že določene ali predvidene za naslednike, vendar pa po prevzemu ne nameravajo nadaljevati s kmetovanjem, se ta kriterij nanaša na zagotovilo gospodarjev, da bodo našli in določili naslednika, ki bo prevzel kmetijo in tudi nadaljeval s kmetovanjem. »Dokler namreč obstaja motivacija gospodarja za iskanje naslednika in ohranitev posestne celovitosti ter socio-proizvodne funkcije, kmetije ne moremo uvrstiti med nasledstveno nevitalne« (Kerbler 2006, 202). Zaradi velike želje po ohranjanju kmetijske tradicije, lastnega dela in dela predhodnih generacij poskušajo gospodarji med sorodniki poiskati najbolj zanesljive naslednike in tako se v praksi dogaja, da se nekateri, potem ko prevzamejo kmetijo, preselijo in začnejo kmetovati, s čimer kmetije v celoti ohranjajo proizvodno in socialno funkcijo (Kovačič 1996). Za kmetije, na katerih so gospodarji zagotovo prepričani, da ne bodo našli naslednikov, ki bi kmetije prevzeli in na njih tudi nadaljevali s kmetovanjem, sicer še vedno obstaja možnost, da jih bodo po smrti gospodarja podedovale osebe, ki bodo na njih nadaljevale s kmetovanjem, vendar lahko 
sklepamo, da je verjetnost, da bi se to zgodilo, zelo majhna, še zlasti, ker so obravnavane kmetije na območjih z omejenimi možnostmi za kmetovanje. Poleg tega menimo, da so gospodarji, ki so glede nasleditve na kmetiji tako odgovorili, že izčrpali vse možnosti in izgubili vsako upanje.

Na podlagi kriterijev so bile, kot je razvidno iz slike 1, kmetije najprej razvrščene $\mathrm{v}$ štiri skupine (A, B, C in D). Stanja (načrtovanega, predvidenega) nasledstva na hribovskih kmetijah v Sloveniji smo določili z združitvijo skupin A, B, C in D v para na podlagi sklepov o tem, ali bo glede na dogodke, ki so načrtovani (predvideni) v zvezi z nasleditvijo na kmetiji, to $\mathrm{v}$ prihodnje prevzel naslednik, ki se bo na njej še naprej ukvarjal s kmetovanjem. Na ta način smo opredelili dve obliki stanj nasledstva na hribovskih kmetijah v Sloveniji, ki ju $\mathrm{v}$ nadaljevanju zaradi lažje ponazoritve izražamo z oznakama $\mathrm{Y}_{i}=0$ in $\mathrm{Y}_{i}=1$, pri čemer (skrajšano) pomeni:

$\mathrm{Y}_{i}=1$ kmetijo bo prevzel naslednik, ki se bo na njej še naprej ukvarjal s kmetovanjem (skupini A in C);

$\mathrm{Y}_{i}=0$ na kmetiji ne bo prišlo do nasleditve oziroma bo to prevzel naslednik, ki se ne bo ukvarjal s kmetovanjem (skupini B in D).

Natančnejša opredelitev posameznih stanj nasledstva na hribovskih kmetijah v Sloveniji je razvidna iz algoritma, ki ga prikazuje slika 1.

\subsection{Izbor kmetij za anketiranje in opredelitev raziskovalnega vzorca}

Osnova za izbor kmetij za anketiranje je bil podatek o številu hribovskih kmetij v Sloveniji in o naseljih, v katerih so te kmetije, pri čemer smo oboje pridobili iz ažurnega Statističnega registra kmetijskih gospodarstev v Sloveniji. Kriterijem za določitev hribovskih kmetij v Sloveniji je ustrezala 6801 hribovska kmetija. Ker smo želeli, da bi bil vzorec čim reprezentativnejši, smo hoteli pridobiti podatke za vsaj $10 \%$ hribovskih kmetij, ki smo jih opredelili kot ciljno skupino. Ker smo ugotovili, da je bila pri drugih (tujih) raziskavah nasledstva na kmetijah pri anketiranju po pošti vrnjena približno tretjina anketnih vprašalnikov (pri raziskavi, ki sta jo opravila Kimhi in Lopez (1999), je bilo vrnjenih 29,3 \%, pri raziskavi, ki jo je opravil Tietje (2004), pa 29 \% anketnih vprašalnikov), smo izbrali 3000 hribovskih kmetij, saj smo predvidevali, da bi potencialna tretjina vrnjenih vprašalnikov pomenila $14,7 \%$ vseh kmetij, izbranih na podlagi kriterijev. Če so bile v naselju le ena do tri hribovske kmetije, smo izbrali vse, v naseljih s štirimi ali več hribovskimi kmetijami pa smo jih izbrali naključno na proporcionalni način, vendar tako, da je bila v vsakem od teh naselij izbrana vsaj tretjina hribovskih kmetij.

Anketiranje smo opravili junija 2005 po pošti. Anketni vprašalniki so bili naslovljeni na gospodarje in gospodarice kmetij. Od 3000 hribovskih kmetij je anketne vprašalnike vrnilo 821 naslovljenih gospodarjev kmetij, kar je 27,4 \% vseh kmetij, ki smo jih vključili $\mathrm{v}$ anketiranje. Po tem, ko smo iz nadaljnje empirične analize izključili vse tiste anketne vprašalnike, ki niso bili izpolnjeni v celoti, je končni raziskovalni vzorec obsegal 789 hribovskih kmetij oziroma 11,6 \% vseh hribovskih kmetij, ki smo jih na podlagi kriterijev opredelili kot ciljno skupino. 
Slika 1: Algoritem za določitev stanj nasledstva na hribovskih kmetijah v Sloveniji

Figure 1: Algorithm for determination of the succession statuses on mountain farms in Slovenia

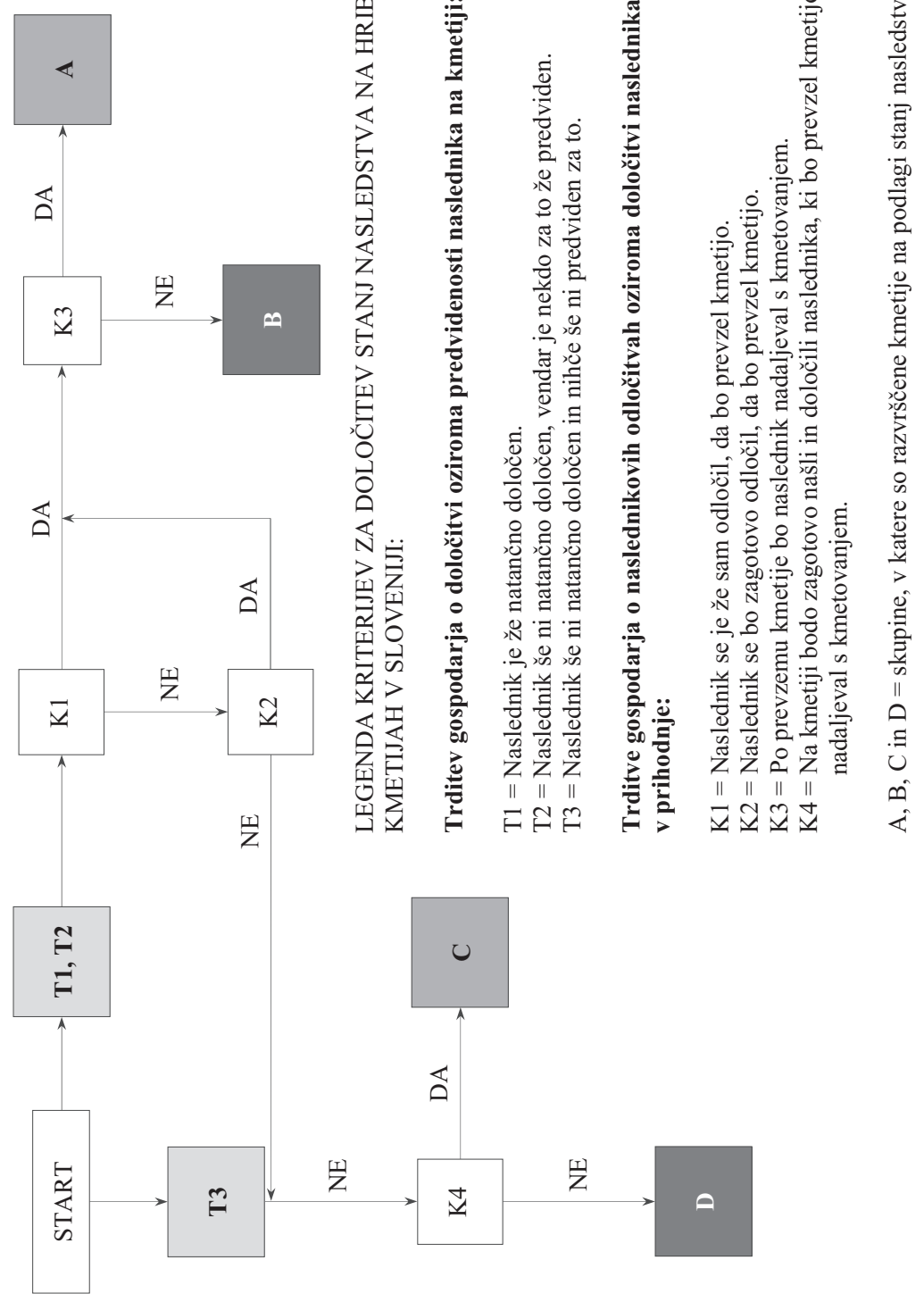




\section{REZULTATI}

$\mathrm{Na}$ podlagi odgovorov izpraševancev o stanjih nasledstva, o predvidenih namerah in odločitvah posameznikov v zvezi z nasledstvom in kmetovanjem v prihodnje ter s pomočjo algoritma, predstavljenega na sliki 1 , smo analizirane kmetije razvrstili $\mathrm{v}$ štiri skupine. Številčno razvrstitev kmetij po posameznih skupinah prikazuje slika 2.

Kot je razvidno iz slike 2, sodi v skupino, ki je označena kot T1 ali T2, 551 kmetij, kar je 69,8 \% analiziranih kmetij, katerih gospodarji trdijo, da so nasledniki že natančno določeni oziroma predvideni. V skupino T3, kjer nasledniki še niso natančno določeni oziroma za to še ni nihče predviden, pa sodi preostalih 30,2 \% analiziranih kmetij. Iz skupine T1 ali T2 izhaja skupina A, v kateri je 409 kmetij, kar je 51,8 \% vseh analiziranih kmetij. Na njih so se določeni ali predvideni nasledniki že sami odločili, da bodo kmetije prevzeli in po svojem prevzemu tudi nadaljevali s kmetovanjem.

Iz T1 ali T2 je izpeljana še skupina B, v kateri je 83 kmetij ali 10,5 \% vseh analiziranih kmetij. Na teh kmetijah so se določeni ali predvideni nasledniki sicer odločili, da bodo gospodarje nasledili, vendar po svojem prevzemu ne bodo nadaljevali s kmetovanjem. Skupno je torej v skupinah A in B 492 kmetij, preostale kmetije, ki prav tako sodijo v skupino T1 ali T2 (skupno 59), pa so bile razvrščene v skupino D, saj se po mnenjih gospodarjev določeni ali predvideni nasledniki še niso odločili, ali bodo prevzeli kmetije (K1), in se za to zagotovo tudi ne bodo odločili (K2), na njih pa gotovo tudi ne bodo našli in določili naslednikov, ki bi prevzeli kmetije in tudi nadaljevali s kmetovanjem (K4). To pomeni, da vseh $72 \mathrm{kmetij}(9,1 \%$ vseh analiziranih kmetij), ki so bile razvrščene v skupino $\mathbf{C}$, izhaja iz skupine, označene s T3. Za te kmetije je značilno, da na njih nasledniki še niso natančno določeni in nihče še ni predviden za to, vendar gospodarji oziroma gospodarice teh kmetij menijo, da bodo zagotovo našli in določili naslednika, ki bo prevzel kmetijo in tudi nadaljeval s kmetovanjem.

Pri 225 kmetijah (25,2 \% kmetij raziskovalnega vzorca), ki so bile razvrščene v skupino D, nas je še dodatno zanimalo, kaj se bo zgodilo s kmetijami, če na njih zagotovo ne bodo našli in določili naslednika, ki bi kmetijo prevzel in na njej nadaljeval s kmetovanjem, kot trdijo izprašanci. Na vprašanje je odgovorila nekaj več kot polovica izprašancev $(52,4$ \%). Skoraj tri četrtine (73,6 \%) jih je odgovorilo, da ne vedo, 17,1\% jih je menilo, da jim je vseeno oziroma da se bodo s tem vprašanjem ukvarjali drugi, 8,2 \% kmetij naj bi bilo zaradi tega, potem ko bodo gospodarji na njih prenehali gospodariti, opuščenih, medtem ko naj bi se $1 \%$ kmetij prodal še v času sedanjih gospodarjev oziroma gospodaric.

Kot smo opisali in utemeljili v prejšnjem poglavju, smo skupine A, B, C in D združili v para ter tako opredelili dve obliki stanj nasledstva na hribovskih kmetijah, ki smo ju izrazili z oznakama $\mathrm{Y}_{i}=0$ in $\mathrm{Y}_{i}=1$.

Razmerje med deleži 789 kmetij raziskovalnega vzorca, ki jim ustreza določeno stanje nasledstva, prikazuje slika 3. Rezultati kažejo, da bodo 60,9\% hribovskih kmetij prevzeli nasledniki, ki se bodo na njih še naprej ukvarjali s kmetovanjem $\left(\mathrm{Y}_{i}=1\right)$, na 39,1 \% hribovskih kmetij pa do nasleditve ne bo prišlo oziroma bodo te prevzeli nasledniki, ki se ne bodo ukvarjali s kmetovanjem $\left(\mathrm{Y}_{i}=0\right)$.

Iz slike 3 je razvidno, da rezultati naše raziskave nasprotujejo podatkom Popisa kmetijskih gospodarstev leta 2000, saj ima po le-teh naslednike izbranih 32,8 \% hribovskih kmetij, 
Slika 2: Število kmetij po opredeljenih skupinah stanj nasledstva na hribovskih kmetijah raziskovalnega vzorca

Figure 2: Number of farms by determined groups of the succession statuses on mountain farms included in the research sample

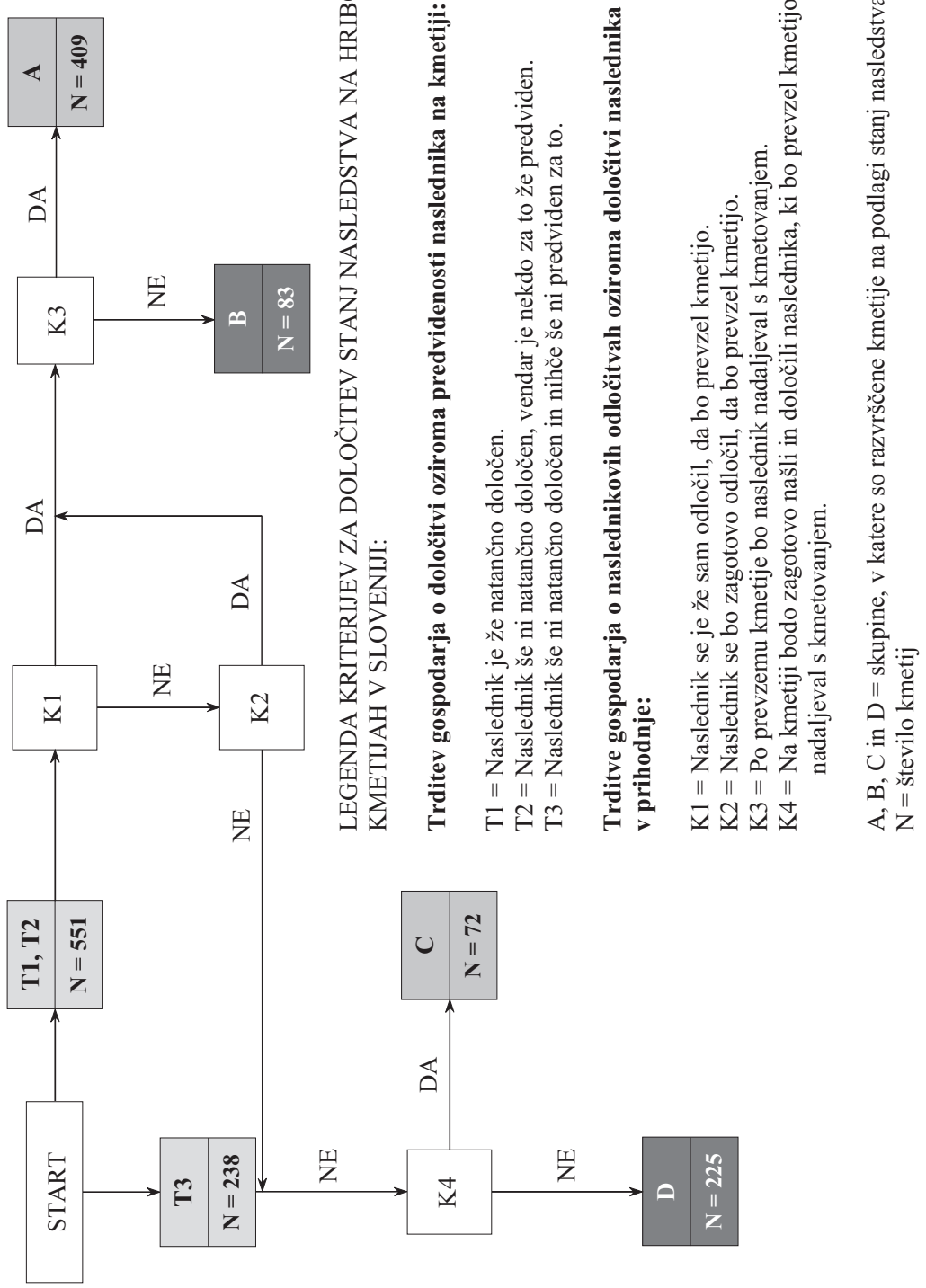


$67,2 \%$ pa teh nima izbranih. Da bi lahko rezultate primerjali, smo z anketiranjem pridobili tudi podatke, na podlagi katerih smo lahko naslednike in $\mathrm{s}$ tem nasledstvo na kmetijah opredelili tako kot $\mathrm{v}$ popisu.

Slika 3: Zastopanost analiziranih kmetij glede na stanje nasledstva na njih Figure 3: Proportion of analysed farms according to their succession status

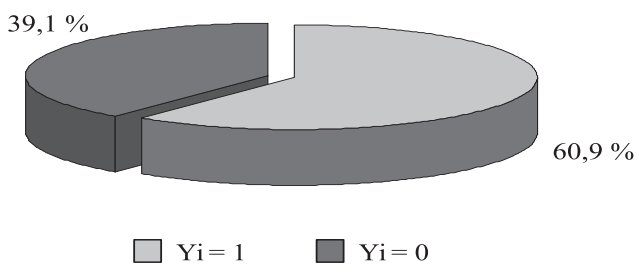

Rezultati analize kažejo, da je imelo 26,2 \% analiziranih hribovskih kmetij izbranega naslednika, torej osebo (kot je to opredeljeno v popisu), ki živi v gospodarjevem gospodinjstvu in naj bi za sedanjim gospodarjem prevzela in vodila kmetijo. Opredelitev, da bo oseba po prevzemu kmetije kmetijo tudi vodila, $\mathrm{v}$ teh okoliščinah razumemo, da bo oseba $\mathrm{s}$ kmetovanjem nadaljevala, vendar pa ne moremo $\mathrm{z}$ gotovostjo trditi, da je $\mathrm{z}$ besedo voditi res mišljeno nadaljevati s kmetovanjem.

Če bi torej na analiziranih kmetijah stanje nasledstva določili na podlagi kriterijev popisa, bi v primerjavi s številom kmetij, ki smo jih v raziskavi razvrstili v skupino A, kot kmetije z naslednikom opredelili le malo več kot polovico (50,6\%) kmetij. Razlika nastane, ker so na preostalih 49,4 \% analiziranih kmetijah, ki so razvrščene v to skupino, nasledniki osebe, ki ne živijo v istem gospodinjstvu kot gospodar. Kot se je pokazalo v raziskavi, pa teh kmetij ne moremo opredeliti kot kmetij brez naslednika, kot bi jih lahko sicer na podlagi kriterijev popisa. Po trditvah gospodarjev so namreč na teh kmetijah osebe, ki sicer ne živijo v gospodarjevem gospodinjstvu, že določene za naslednike oziroma so te osebe za naslednike že predvidene, poleg tega pa so se tudi same že odločile, da bodo prevzele kmetije in po svojem prevzemu nadaljevale s kmetovanjem.

Naše rezultate o zastopanosti analiziranih kmetij glede na stanje nasledstva na njih in argumente v zvezi s tem potrjuje tudi raziskava M. Kovačiča (1996). Avtor je na podlagi podrobnejše analize podatkov o predvidenem prevzemniku na kmečkih gospodarstvih iz popisa prebivalstva iz leta 1991, ki je vključeval tudi dodaten vprašalnik o kmetijstvu, za evropsko primerljive kmetije $(\mathrm{EPK})^{4}$ ocenil, da je »na kakih $60 \%$ kmetij nasledstvo tako ali drugače zagotovljeno, okrog $40 \%$ kmetij pa je na tem, da bodo z iztekom sedanje generacije njihovih prebivalcev prenehale obstajati kot proizvodne enote« (Kovačič 1996, 81). Med kmetije, na katerih je nasledstvo tako ali drugače zagotovljeno, je uvrstil 28,6 \% kmetij z zagotovljenim nasledstvom, 9,4\% kmetij, na katerih je predvideni prevzemnik mladoleten in se še ni odločil, ter $20 \%$ kmetij, ki imajo samo dediča, oziroma kmetij, ki nimajo prevzemnika oziroma dediča. Uvrstitev slednjih v navedeno skupino utemeljuje: »Dediči so praviloma sorodniki, ki živijo drugje, večinoma v mestih in se tako ne ukvarjajo

${ }^{4}$ Upoštevane so vse EPK v Sloveniji in ne le tiste, ki so tudi hribovske kmetije. 
s kmetovanjem. Velik del teh občasno prihaja pomagat pri kmetovanju, in tako se v praksi dogaja, da se nekateri potem, ko prevzamejo kmetijo, preselijo in začnejo kmetovati. Mnogi samo prevzamejo dediščino, kmetovanje pa opustijo. Nimamo analiz, kolikšen je delež enih ali drugih. Če zadevo poenostavimo, lahko vzamemo, da je vsakih polovica (od 37,7 \%). Kmetij, ki nimajo niti prevzemnika niti dediča, je slaba četrtina. Za pretežni del teh kmetij lahko predvidevamo, da bodo ugasnile kot proizvodne enote, ko bodo ljudje obnemogli. V praksi pa se vendarle dogaja, da se tudi za take kmetije najdejo prevzemniki, ki kmetijo ohranijo v proizvodni funkciji, zlasti če so te večje. Vzemimo, da je takih $20 \%$, kar ustreza deležu dopolnilnih oziroma ostarelih kmetij z več kot 5 hektarji kmetijske zemlje.« (Kovačič 1996, 81).

\section{APLIKACIJA REZULTATOV RAZISKAVE NA POPIS KMETIJ}

Čeprav zajema raziskovalni vzorec skoraj dvanajstino kmetij, ki smo jih na podlagi kriterijev opredelili kot ciljno skupino, smo se želeli o njegovi reprezentativnosti prepričati in ugotoviti, kakšno je bilo stanje nasledstva, opredeljeno v naši raziskavi, na popisanih kmetijah ciljne skupine leta 2000 . V ta namen smo na podlagi rezultatov anketiranja oblikovali model ${ }^{5}$ in ga prenesli na Popis kmetijskih gospodarstev leta $2000^{6}$, in sicer na 6733 hribovskih kmetij, ki so ustrezale kriterijem za opredelitev hribovskih kmetij v raziskavi.

Rezultati aplikacije so potrdili, da je bil izbrani raziskovalni vzorec reprezentativen - izid $\mathrm{Y}_{i}=1$ je bil namreč dodeljen $62,4 \%$ popisanih kmetij, izid $\mathrm{Y}_{i}=0$ pa je bil s prenosom postavljenega modela določen za 37,6 \% kmetij zajetih v popis (slika 4). Razlika v zastopanosti kmetij po izidih odvisne spremenljivke $\mathrm{Y}_{i}$ je torej (v primerjavi s kmetijami v vzorcu) $\mathrm{v}$ obeh primerih znašala $1,5 \%$.

Slika 4: Zastopanost hribovskih kmetij v Sloveniji po Popisu kmetijskih gospodarstev leta 2000 glede na izid odvisne spremenljivke $Y_{i}$, ki ponazarja stanje nasledstva na kmetiji

Figure 4: Proportion of mountain farms in Slovenia upon the Agricultural census of 2000, according to the outcome of the variable $Y_{i}$, which represents succession status on a farm

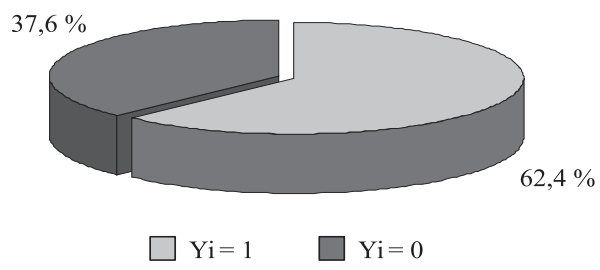

Prenos rezultatov anketiranja na popis tudi omogoča, da lahko stanje nasledstva, opredeljeno v raziskavi, določimo za vsako popisano hribovsko kmetijo in ga tako primerjamo

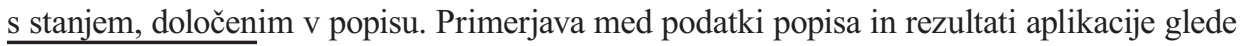

5 Podrobnosti o oblikovanju modela so opisane v avtorjevi doktorski disertaciji (2007).

6 Za prenos modela nasledstva na hribovskih kmetijah je Statistični urad Republike Slovenije leta 2004 posredoval t.i. deindividualizirane podatke Popisa kmetijskih gospodarstev leta 2000 na mikroravni. 
zastopanosti kmetij po stanjih nasledstva na njih kaže (slika 5), da na 43,2 \% hribovskih kmetij, ki po podatkih popisa nimajo izbranega naslednika, do nasleditve dejansko ne bo prišlo oziroma da se nasledniki, če bo do tega prišlo, ne bodo ukvarjali s kmetovanjem $\left(\mathrm{Y}_{i}=0\right)$, na preostalih $56,8 \%$ hribovskih kmetij, ki po uradnih podatkih prav tako nimajo naslednika, pa naj bi glede na kriterije $\mathrm{v}$ raziskavi prišlo do nasledstva, prevzemniki pa naj bi na njih tudi nadaljevali s kmetovanjem $\left(\mathrm{Y}_{i}=1\right)$.

Slika 5: Delež hribovskih kmetij glede na opredelitev nasledstva v Popisu kmetijskih gospodarstev leta 2000 in $v$ raziskavi

Figure 5: Proportion of mountain farms according to the definition of the succession within the Agricultural census of 2000 and in the research

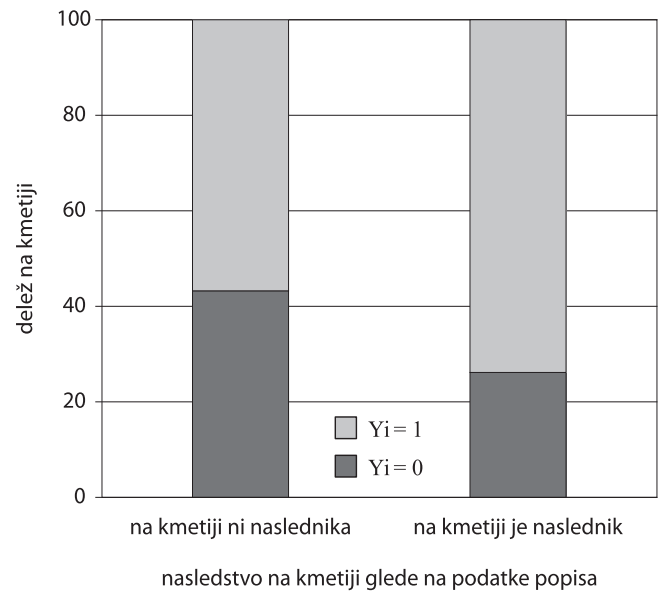

73,9 \% kmetij, za katere smo na podlagi aplikativnega modela izračunali, da bo na njih do nasleditve prišlo, njihovi prevzemniki pa naj bi tudi nadaljevali s kmetovanjem $\left(\mathrm{Y}_{i}=1\right)$, ima naslednika tudi po podatkih popisa. Vendar pa primerjava podatkov kaže tudi, da na 26,1 $\%$ kmetij, ki sicer po podatkih popisa imajo naslednika, do nasleditve ne bo prišlo oziroma da se nasledniki, če bo do tega prišlo, s kmetovanjem ne bodo ukvarjali. Tem kmetijam je bil zato dodeljen izid $\mathrm{Y}_{i}=0$. To lahko delno interpretiramo kot napako pri prenosu postavljenega modela verjetnosti na izbrane hribovske kmetije v Sloveniji, v veliki meri pa je najbrž ta podatek pravilen, saj s popisom niso ugotavljali, ali se je za prevzem odločila tudi oseba, ki je bila za to predvidena in naj bi za sedanjim gospodarjem vodila kmetijo, niti ali bo ta oseba po prevzemu nadaljevala s kmetovanjem (predvidevamo lahko, da vodenje kmetije, kot je to opredeljeno v popisu, ne pomeni povsem zagotovo, da bodo na njej tudi kmetovali).

$\mathrm{Da}$ je razvrstitev hribovskih kmetij po stanjih nasledstva, opredeljenih $\mathrm{v}$ raziskavi, ustreznejša in v nasprotju z rezultati popisa izraža dejansko stanje (predvidenega, načrtovanega) nasledstva, kažejo tudi izračuni povprečnih vrednosti nekaterih strukturnih dejavnikov kmetij (preglednica 1), katerih podatki so bili pridobljeni s popisom: število oseb v gospodarjevem gospodinjstvu (OSEB), polnovredna delovna moč (PDM), število glav ve- 
like živine (GVŽ), površina kmetijskih zemljišč v uporabi (KZU) in ekonomska velikost kmetije (ESU). Raziskovalci, ki so se ukvarjali s proučevanjem nasledstva na kmetijah ${ }^{77}$, za obravnavane dejavnike ugotavljajo, da se s povečevanjem vrednosti teh dejavnikov povečuje tudi verjetnost nasledstva in obratno.

Preglednica 1: Povprečna vrednost posameznih strukturnih dejavnikov hribovskih kmetij glede na opredelitev nasledstva v Popisu kmetijskih gospodarstev leta 2000 in v raziskavi

Table 1: The average value of single structural factors of mountain farms, according to determination of the succession within the Agricultural census of 2000 and in the research

\begin{tabular}{|l|c|c|c|c|c|}
\hline Stanje nasledstva & OSEB & PDM & GVŽ & KZU* & ESU \\
\hline Na kmetiji je naslednik** & 4,60 & 1,68 & 8,41 & 8,31 & 3,73 \\
\hline Na kmetiji ni naslednika** & 3,62 & 1,36 & 6,04 & 6,83 & 2,77 \\
\hline$Y_{i}=1$ & 4,45 & 1,87 & 9,17 & 9,21 & 4,05 \\
\hline$Y_{i}=0$ & 3,08 & 0,79 & 2,82 & 4,09 & 1,44 \\
\hline
\end{tabular}

* Površina $v$ hektarjih.

** Stanje nasledstva na kmetiji glede na podatke popisa.

Vir: Statistični urad Republike Slovenije 2004.

Iz preglednice 1 je razvidno, da so razmerja med povprečnimi vrednostmi obravnavanih dejavnikov veliko izrazitejša pri hribovskih kmetijah, razvrščenih po stanjih nasledstva glede na kriterije raziskave, kot pa pri kmetijah, razvrščenih glede nasledstva po kriterijih popisa.

Da je $\mathrm{v}$ primerjavi s popisom opredelitev nasledstva $\mathrm{v}$ raziskavi ustreznejša in $\mathrm{s}$ tem tudi razvrstitev hribovskih kmetij glede na stanja nasledstva, potrjujejo tudi izračuni $\mathrm{v}$ preglednici 2. Povprečne vrednosti izbranih dejavnikov so namreč pri kmetijah, ki so bile po kriterijih popisa opredeljene kot kmetije brez naslednikov, po kriterijih v raziskavi pa jim je bil glede stanja nasledstva dodeljen izid $\mathrm{Y}_{i}=1$, precej višje in primerljivejše s povprečnimi vrednostmi dejavnikov, izračunanih za vse kmetije, ki jim je bil dodeljen izid $\mathrm{Y}_{i}=1$, kar je prikazano v preglednici 1 .

Preglednica 2: Povprečna vrednost posameznih strukturnih dejavnikov hribovskih kmetij glede na opredelitev nasledstva v Popisu kmetijskih gospodarstev leta 2000 in v raziskavi

Table 2: The average value of single structural factors of mountain farms, according to determination of the succession within the Agricultural census of 2000 and in the research

\begin{tabular}{|l|c|c|c|c|c|}
\hline Stanje nasledstva & OSEB & PDM & GVŽ & KZU* & ESU \\
\hline Na kmetiji ni naslednika** $/ \mathrm{Y}_{\mathrm{i}}=1$ & 4,18 & 1,80 & 8,47 & 8,86 & 3,77 \\
\hline Na kmetiji je naslednik**/ $\mathrm{Y}_{\mathrm{i}}=0$ & 3,82 & 0,84 & 2,96 & 4,09 & 1,49 \\
\hline
\end{tabular}

* Površina v hektarjih.

** Stanje nasledstva na kmetiji glede na podatke popisa.

Vir: Statistični urad Republike Slovenije 2004.

7 Avtorji raziskav o nasledstvu na kmetijah so v prispevku našteti v poglavju Metodologija. 
Glede na izračunane povprečne vrednosti izbranih dejavnikov (preglednica 2) je mogoče sklepati, da je za hribovske kmetije, ki so bile po popisu opredeljene kot kmetije z naslednikom, glede na kriterije raziskave pa kot kmetije, na katerih do nasleditve ne bo prišlo ali jih bo prevzel naslednik, ki se ne bo ukvarjal s kmetovanjem $\left(\mathrm{Y}_{i}=0\right)$, slednja opredelitev ustreznejša. Prav tako je opredelitev glede na kriterije raziskave ustreznejša tudi za kmetije, ki so bile po popisu opredeljene kot kmetije brez naslednika, po kriterijih raziskave pa so bile opredeljene kot kmetije, na katerih bo do nasledstva prišlo, prevzemniki pa naj bi na njih tudi nadaljevali s kmetovanjem $\left(\mathrm{Y}_{i}=1\right)$.

\section{SKLEP}

Raziskava je pokazala, da uradni statistični podatki ne izražajo dejanskega stanja nasledstva na hribovskih kmetijah in da je stanje ugodnejše, kot kažejo podatki Popisa kmetijskih gospodarstev v Sloveniji leta 2000. V primerjavi s popisom namreč kriteriji, ki smo jih za določitev stanja nasledstva opredelili v raziskavi, ne omejujejo naslednika le na gospodarjevo gospodinjstvo ter vključujejo tudi informacije o odločitvah in namerah določenih ali predvidenih naslednikov glede prevzema in nadaljnjega kmetovanja ter mnenja, pričakovanja in zagotovila gospodarjev glede tega.

Čeprav smo se v raziskavi osredotočili na proučevanje nasledstva na hribovskih kmetijah, so postavljeni kriteriji za določanje stanj nasledstva splošni in veljajo za vse kmetije. Ker je podatek o stanju nasledstva na kmetijah ključen za določanje smernic za nadaljnji razvoj kmetijstva, bi moral naslednji popis kmetijstva in vsi nadaljnji popisi vsebovati vprašanja, ki bi omogočala določitev stanj nasledstva na kmetijah na podlagi algoritma, ki je bil zasnovan za raziskavo.

\section{Viri in literatura}

Corsi, A. 2004: Intra-family succession in Italian farms. Medmrežje: http://www.child-centre.it/papers/child21_2004.pdf(17.10.2005).

Dernulc, S., Iljaš, U., Kutin, B., Orešnik, I., Cunder, T., Golež, M., Juvančič, L. 2002: Popis kmetijskih gospodarstev, Slovenija 2000. Ljubljana.

Fasterding, F. 1995: Hofnachfolge in Westdeutschland. Landbauforschung Völkenrode 45/1, 48-66. Braunschweig.

Fasterding, F. 1999: Nachfolge in ladwirtschaftlichen Betrieben in Deutschland. Berichte über Landwirtschaft 77/2, 165-183. Berlin.

Gale, F. H. 1993: Why did the number of young farm entrants decline? American journal of agricultural economics 75, 138-146. Malden.

Glauben, T., Tietje, H., Weiss, C. H. 2002: Intergenerational succession on family farms: evidence from survey data. Medmrežje: http://www.food-econ.uni-kiel.de/Workingpaper/Ewp0202.pdf(12. 9. 2003).

Glauben, T., Tietje, H., Weiss, C. H. 2003: Agriculture on the move: exploring regional differences in farm exit rates. Medmrežje: http://www.food-econ.uni-kiel.de/Workingpaper/ Fe0308.pdf (9. 12. 2003). 
Glauben, T., Tietje, H., Weiss, C. H. 2004: Succession in agriculture: a probit and competing risk analysis. Medmrežje: http://www.food-econ.uni-kiel.de/Workingpaper/FE0406.pdf (7. 7. 2004).

Hennessy, T. 2002: Modelling succession on Irish dairy farms. Medmrežje: http://ageconsearch.umn.edu/bitstream/24953/1/cp02he34.pdf (3. 9. 2003)

Hennessy, T. 2004: Examining the factors that affect intergenerational transfer in Irish farming: an application of limited dependent variable models (osebni vir, 8. 4. 2004).

Hribernik, F. 1994: Sklepanje in razveljavljanje zakonskih zvez v Sloveniji s posebnim ozirom na kmečko prebivalstvo. IB revija 28/12, 34-45. Ljubljana.

Ilešič, S. 1972: Slovenske pokrajine. Geografska regionalizacija Slovenije. Geografski vestnik 44, 9-31. Ljubljana.

Juvančič, L. 2002: Model odločanja o zaposlovanju na kmečkih gospodarstvih v Sloveniji. Doktorska disertacija, Biotehniška fakulteta. Ljubljana.

Juvančič, L. 2006: Determinants of farm survival and growth in Slovenia (1991-2000). Medmrežje: http://www.fat.admin.ch/eaae96/abstracts/s25.pdf (10. 4. 2006).

Kerbler, B. 2002: Geografske značilnosti hribovskih kmetijskih gospodarstev v občini Ribnica na Pohorju. Diplomsko delo, Oddelek za geografijo, Filozofska fakulteta. Ljubljana.

Kerbler, B. 2003a: Aplikativna razvojna tipologija hribovskih kmetijskih gospodarstev v občini Ribnica na Pohorju. Geografski vestnik 75/1, 103-116. Ljubljana.

Kerbler, B. 2003b: A conception of developmental typology of mountain farms: a case study of the municipality Ribnica na Pohorju (Zasnova razvojne tipologije hribovskih kmetijskih gospodarstev: na primeru občine Ribnica na Pohorju). Acta Geographica Slovenica 43/2, 87-120. Ljubljana.

Kerbler, B. 2006: Demografski potencial hribovskih kmetij na Dravskem Pohorju. Dela 25, 193-205. Ljubljana.

Kerbler, B. 2007: Povezanost nasledstva na hribovskih kmetijah v Sloveniji z njihovo socialnogeografsko strukturo. Doktorska disertacija, Oddelek za geografijo, Filozofska fakulteta. Ljubljana.

Kimhi, A., Bollman, R. 1999: Family farm dynamics in Canada and Israel: the case of farm exits. Agricultural economics 21/1, 69-79. Oxford.

Kimhi, A., Lopez, R. 1999: A note on farmers' retirement and succession considerations: evidence from a household survey. Journal of agricultural economics 50/1, 154-162. Oxford.

Kimhi, A., Nachlieli, N. 2001: Intergenerational succession on Israeli family farms. Journal of agricultural economics 52/2, 45-58. Oxford.

Kovačič, M. 1996: Socio-ekonomska in velikostna struktura kmetij v Sloveniji v obdobju 1981-1991. Biotehniška fakulteta. Ljubljana.

Medmrežje 1: http://economics.about.com/cs/economicsglossary/g/ex_ante.htm (27. 8. 2006).

Medmrežje 2: http://economics.about.com/library/glossary/bldef-ex-post.htm (27. 8. 2006).

Pfeffer, M. 1989: Part-time farming and the stability of family farms in the Federal Republic of Germany. European review of agricultural economics 16, 425-444. Oxford.

Pietola, K., Väre, M., Lansink, A. O. 2003: Timing and type of exit from farming: farmers' early retirement programmes in Finland. European review of agricultural economics 30/1, 99-116. Oxford. 
Robič, T. 1988: Razvojni cilji kmetijsko nerazvitih območij. Kmetijski priročnik 1989, 28-53. Ljubljana.

Robič, T. 1990: Območja z omejenimi naravnimi dejavniki za kmetijstvo v SR Sloveniji. Ljubljana.

Statistični urad Republike Slovenije 2003: Raziskovanje strukture kmetijskih gospodarstev, junij 2003. Navodila za popisovalce in inštruktorje. Ljubljana.

Statistični urad Republike Slovenije 2004: Deindividualizirani podatki Popisa kmetijskih gospodarstev leta 2000 na mikroravni. Ljubljana.

Stiglbauer, A., M., Weiss, C., R. 2000: Family and non-family succession in Upper-Austrian farm sector. Cahiers d'économie et sociologie rurales 54, 5-26. Ivry.

Tietje, H. 2003: Hofnachfolgesituation in Deutschland - Eine empirische Analyse von Querschnittsdaten auf Kreisebene. Medmrežje: http://www.food-econ.uni-kiel.de/Workingpaper/Ewp0301.pdf (22. 9. 2003).

Tietje, H. 2004: Hofnachfolge in Schleswig-Holstein. Doktorska disertacija, Institut für Ernährungswirtschaft und Verbrauchslehre der Christian-Albrechts-Universität zu Kiel. Kiel.

Väre, M., Weiss, C. H. 2003: Farmers' succession considerations and realization of succession plans. Medmrežje: http://www.mm.helsinki.fi/ hsmakine/nova/Vare.pdf (24. 2. 2004).

Väre, M., Weiss, C. H., Pietola, K. 2006: Should one trust a farmer's succession plan? Empirical evidence on the intention-behaviour discrepancy from Finland. Medmrežje: http://www.fat.admin.ch/eaae96/abstracts/s17.pdf (10. 4. 2006).

Weiss, C. R. 1999a: Farm growth and survival: econometric evidence for individual farms in Upper Austria. American journal of agricultural economics 81, 103-116. Malden.

Weiss, C. R. 1999b: Zum Ausscheiden landwirtschaftlicher Betriebe: Eine empirische Analyse. Agrarwirtschaft 48-50, 202-209. Hannover.

\section{SUCCESSION STATUS ON MOUNTAIN FARMS IN SLOVENIA}

\section{Summary}

According to the Slovene Agricultural Census of 2000, successors are not chosen on $67.2 \%$ of mountain farms. This proportion is to be concerned, since »assurance of (inter) generational continuation is crucial with regard to the preservation of farming traditions « (Hribernik 1994, 35) since mountain farms are the most important element of the mountain cultural landscape. At the same time this proportion is also unusually high, therefore we have presumed that this figure is incorrect. To confirm our presumption and to determine (to find out) what is the true succession status on mountain farms in Slovenia, an extensive research project was carried out and for this project alone, more accurate criteria for defining the succession rates were created. In the census, however, successors are defined as persons, who should take over a farm and manage it after the existing householder, but inquirers had the option to indicate them on census-paper only among persons, who live in the householder's household. 
To surpass the insufficiency of the Slovene Agricultural Census of 2000 with regard to determining the status of succession on mountain farms in Slovenia, in our research a successor was defined as person, who will take over a farm and manage it after the householder, but it is not necessary that he/she lives in the same household as the householder and that such a person is the householder's offspring. Also some other criteria were considered:

- If a successor is already accurately appointed or someone is expected to take over this role;

- If a successor has decided by his/her own to take over a farm or if a successor will decide definitely to take over a farm;

- If a successor will continue with farming practices after the takeover;

- If a successor, who will take over a farm and also with farming practices, will be found and appointed on a farm definitely.

With a help of the algorithm (Figure 1) two statuses of succession on mountain farms in Slovenia were defined at the base of the criteria. To make the illustration easier, statuses were expressed with the symbols $\mathrm{Y}_{i}=0$ and $\mathrm{Y}_{i}=1$, by which (abridged) means:

$\mathrm{Y}_{i}=1$ a farm will be taken over by a successor, who will continue with farming practices - groups A in C;

$\mathrm{Y}_{i}=0$ there will be no succession on a farm or the farm will be taken over by a successor, who will not continue with farming practices - groups B in D.

Succession status was determined for $11.6 \%$ of those mountain farms in Slovenia, which were surveyed, and were defined as the target group. Results have shown, that in comparison within the data of the Slovene Agricultural Census of 2000, succession status on mountain farms in Slovenia is just the opposite: successors, who will be occupied with farming practices $\left(\mathrm{Y}_{i}=1\right)$, will take over $60.9 \%$ of mountain farms, however, on $39.1 \%$ of mountain farms there will be no succession or farms will be taken over by a successors, who will not be occupied with farming practices $\left(\mathrm{Y}_{i}=0\right)$.

To confirm the representativeness of the results and to find out, what was the succession status defined in the research with regard to mountain farms, which were included in the census in the year 2000, a model was formed on the basis of the results of the survey and transferred onto the Slovene Agricultural Census of 2000, namely 6,733 mountain farms. The results of the application have confirmed that the chosen research sample was representative - namely the outcome $Y_{i}=1$ was assigned to $62.4 \%$ of farms included onto the census, however, with a transfer of the formed model the outcome $Y_{i}=0$ was appointed to $37.6 \%$ of census farms.

Also the calculations of the average values of some structural factors of farms have shown (Table 1), that in opposition to the census results, the classification of mountain farms upon succession status, defined in the research was more adequate and that it reflects the actual succession status. However, the relationship amongst the average values of treated factors are much more distinctive with mountain farms, classified upon succession statuses with regard to the research criteria, as with farms classified regarding succession within the census criteria. 
The formulated criteria for determining succession statuses are general and valid for all farms, irrespective of what research was focused on the study of succession on mountain farms. Since information about succession status on farms is crucial for determining directives for the further development of agriculture, the next agricultural census and all further censuses should contain questions, which would make it possible to determine succession status on farms on the basis of the algorithm, which was developed for the needs of this research.

(Slovensko besedilo prispevka je lektorirala dr. Nina Novak, besedilo v angleškem jeziku pa Finbar O'Mahony.) 